\title{
Post-collisional magmatism around northern Taiwan and its relation with opening of the Okinawa Trough
}

\author{
Kuo-Lung Wang ${ }^{\mathrm{a}, *}$, Sun-Lin Chung ${ }^{\mathrm{a}}$, Chang-Hwa Chen ${ }^{\mathrm{b}}$, Ryuichi Shinjo ${ }^{\mathrm{c}}$, \\ Tsanyao F. Yang ${ }^{\mathrm{a}}$, Cheng-Hong Chen ${ }^{\mathrm{a}}$ \\ ${ }^{a}$ Department of Geology, National Taiwan University, 245 Choushan Road, Taipei, Taiwan \\ ${ }^{b}$ Institute of Earth Sciences, Academia Sinica, P.O. Box 1-55, Nankang, Taipei, Taiwan \\ ${ }^{c}$ Department of Physics and Earth Sciences, University of the Ryukyus, Okinawa, Japan
}

Received 22 September 1998; accepted 24 March 1999

\begin{abstract}
Being part of an active mountain belt formed by oblique collision of the Luzon arc with Asia, northern Taiwan and the offshore islets are marked by a series of latest Pliocene-Quaternary volcanoes whose eruptions have been conventionally ascribed to westward propagation of the Ryukyu volcanic arc. On the basis of new geochemical data, along with supporting geologic and geophysical evidence, we propose instead that this young volcanism resulted from post-collisional lithospheric extension in the northern Taiwan mountain belt and the mantle source regions involved in the melt generation have been significantly modified by the nearby Ryukyu subduction-related processes. Magmas thus produced through the northeast to the southwest in the Northern Taiwan Volcanic Zone (NTVZ) vary from low-K to calc-alkaline and then shoshonitic compositions. Such a spatial geochemical variation, characterized by southwestward increase in enrichments of potassium and incompatible trace elements, runs subparallel to the southwestern part of the present-day Ryukyu Trench. The geochemical variation that can be explained by southwestward decrease in degrees of partial melting of the mantle sources is reconciled with a southwestward-weakening extensional regime observed in the NTVZ. The post-collisional extension in northern Taiwan, furthermore, might have played a role in reactivation of the opening in the middle Okinawa Trough, and gave way to its rapid southwestward propagation with associated development of the Ryukyu subduction zone west of $\sim 124^{\circ} \mathrm{E}$. This nascent subduction, in turn, resulted in abundant submarine volcanoes which delineate an embryo volcanic front along the southern margin of the trough. Therefore, the southwestern Okinawa Trough is not a 'fore-arc' basin as had been previously alleged, but represents an 'atypical' back-arc basin which developed broadly synchronously or prior to its arc-trench system in this particular collision/extension/subduction tectonic environment. (c) 1999 Elsevier Science B.V. All rights reserved.
\end{abstract}

Keywords: northern Taiwan; magmatism; post-collisional extension; Okinawa Trough; Ryukyu subduction

\section{Introduction}

Taiwan is an active mountain belt created by the oblique collision between the northern Luzon arc

\footnotetext{
* Corresponding author. Fax: +88622363 6095; E-mail: klwang@gate.sinica.edu.tw
}

and the Asian continent (Ho, 1986; Teng, 1990). First outlined by Suppe (1981), this mountain belt has been widely regarded as an actualistic example to understand the orogenic build-up by accretionary processes (e.g., Davis et al., 1983; Suppe, 1984; Dahlen and Suppe, 1988). Despite of the ongoing collision in central and southern Taiwan, extensional 
collapse has occurred in the northern part of the mountain belt since Plio-Pleistocene time. Accordingly, Teng (1996) proposed a model for the whole spectrum of the northern Taiwan orogenic evolution, from mountain build-up by collision to subsequent collapse by extension, that lasted for only a few million years. Compared with other collision-related orogens characterized also by extensional collapse (Dewey, 1988; Platt and Visser, 1989; Malavielle, 1993), northern Taiwan may provide the most active and illustrative features for such a tectonic process. On the other hand, interaction between orogenic processes in Taiwan and development of the neighboring Ryukyu Trench and Okinawa Trough, however, remains highly debatable (e.g., Suppe, 1984; Viallon et al., 1986; Teng et al., 1992; Hsu and Sibuet, 1995; Miki, 1995; Hsu et al., 1996). One of the major reasons of the controversy is that the Northern Taiwan Volcanic Zone (NTVZ), conventionally accepted as the westernmost branch of the Ryukyu volcanic arc (cf. Chen, 1990), is virtually located $\sim 150 \mathrm{~km}$ north of the Ryukyu arc system (Fig. 1). Thus, the southwestern Okinawa Trough behaves as a 'fore-arc' basin, in contrast with its northern-central part that develops behind the Ryukyu volcanic arc (see Sibuet et al., 1995 for a recent review). In this paper, we present major and trace element systematics of volcanic rocks from northern Taiwan and the offshore islets which constitute the NTVZ (Fig. 1). A spatial geochemical variation is identified in the NTVZ. We conclude that the NTVZ is not part of the Ryukyu volcanic arc, although subductionrelated processes had modified the mantle sources involved in the magma generation. The NTVZ is suggested to have resulted from a post-collisional lithospheric extension associated with the collapse of the northern Taiwan mountain belt. This extensional regime might have also reactivated the opening of the Okinawa Trough that has been initiated as early as in the Middle Miocene but became inactive due to the arc-continent collision in Taiwan.

\section{Geologic background}

Sitting on the boundary between the Philippine Sea plate and the East Asian continent, the island of Taiwan is not only a collision zone but also a transform region between the opposing Luzon and Ryukyu subduction systems (Fig. 1). The Ryukyu subduction, and the resultant Ryukyu arc-trench, is associated with a back-arc basin in the Okinawa Trough which shows a distinct topography (>2000 m below sea level) and crustal thickness $(<18 \mathrm{~km})$ as compared to those of the neighboring Taiwan orogen (Hirata et al., 1991; Sibuet et al., 1995). Driven by northwestward movement of the Philippine Sea plate, the northern segment of the Luzon arc is generally believed to have collided with the Asian continental margin since about $10 \mathrm{Ma}$ (Teng, 1990). The Taiwan mountain belt, composed of deformed strata of both the Asian continent and the Luzon arc, has been therefore established and reaches a maximum altitude over $3000 \mathrm{~m}$ in the central part (Fig. 1). Whereas this collisional tectonism is still ongoing as evidenced by the prominent crustal shortening in central and southern Taiwan (e.g., Angelier et al., 1986; Yu and Chen, 1994), structural (Suppe, 1984; Lee and Wang, 1988) and seismological (Yeh et al., 1991) data demonstrate that the northern part of the Taiwan mountain belt has been subjected to an extensional deformation in the Quaternary. Thus, the northern Taiwan orogen has virtually gone through the collision orogeny and is in the process of collapsing. Consequently, the orogen reduces its elevation from over $3000 \mathrm{~m}$ in central Taiwan to the rolling hills in the northeastern part and eventually becomes submerged in the offshore area farther to the northeast (Fig. 1).

\section{The Northern Taiwan Volcanic Zone}

The NTVZ comprises two major onland volcanic fields, i.e. the Tatun and the Keelung volcano groups and several offshore volcanoes (Fig. 1). Additionally, an isolated volcanic dome named Tsaolinghsan is located in the westernmost part and is marked by its highly magnesian and potassic nature (Chen, 1990; Chung et al., 1995b). Contrary to the central Ryukyu volcanic arc which existed no later than in the Early Miocene (Kizaki, 1986; Shinjo, 1998), the NTVZ began at $\sim 2.8-2.5 \mathrm{Ma}$ and lasted during the entire Quaternary (Fig. 2). Volcanic rocks from the NTVZ consist dominantly of andesites with calc-alkaline geochemical features, similar to that often observed in the convergent-margin lavas (e.g., 
$125^{\circ} 130^{\circ} \mathrm{E}$

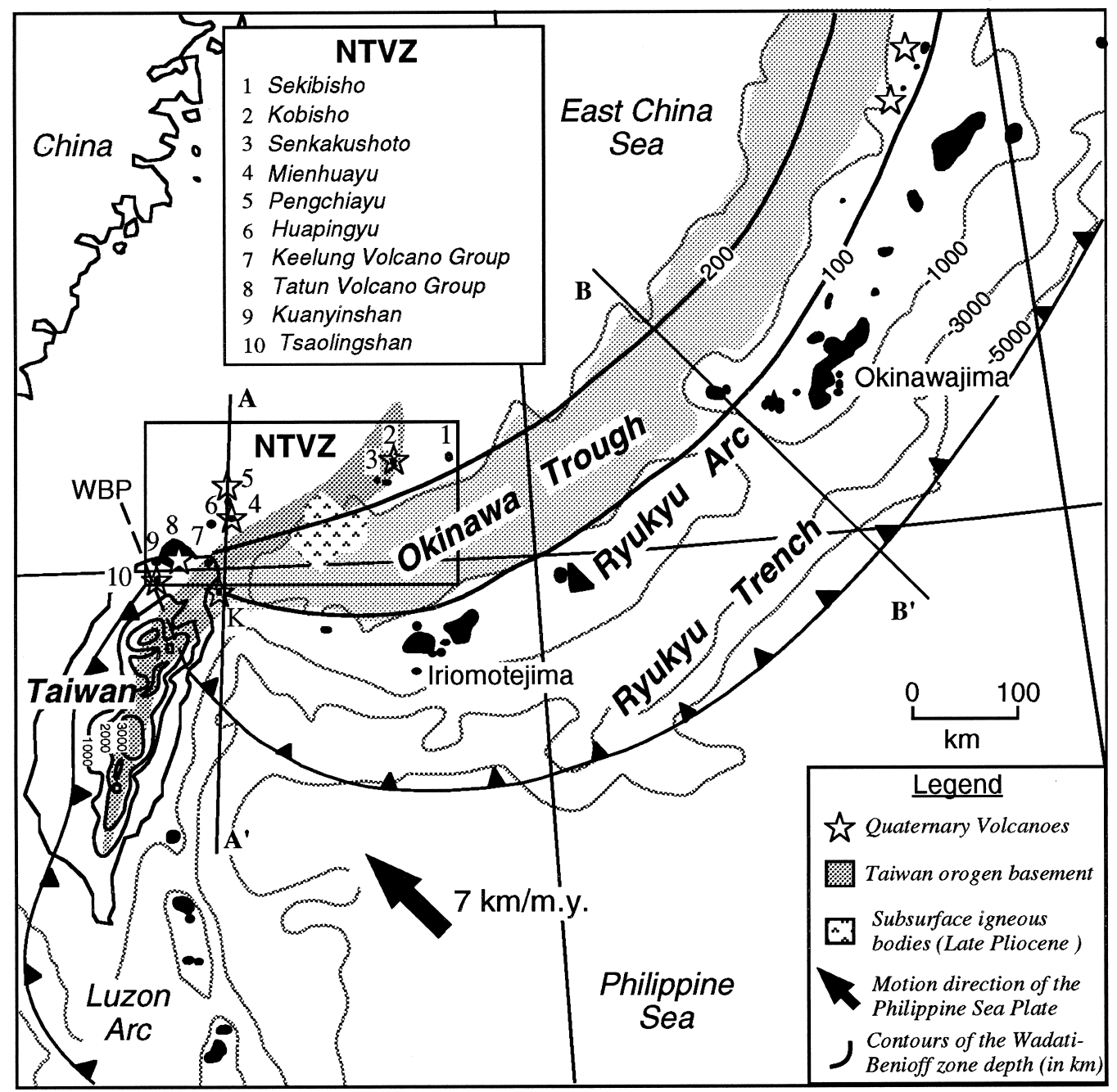

$25^{\circ} \mathrm{N}$

Fig. 1. Map showing the tectonic framework around Taiwan and igneous outcrops of the Northern Taiwan Volcanic Zone (NTVZ). Modified from Chen (1990), Sibuet et al. (1995), Teng (1996) and Kao et al. (1998). Topographic contours, onland and offshore, are in meters. WBP indicates the western boundary of the subducting Philippine Sea plate. Note that the NTVZ is currently located $\sim 200$ $\mathrm{km}$ above the Wadati-Benioff zone. In the westernmost part of the Okinawa Trough, a Quaternary volcanic islet marked with $K$ is the Kueishantao.

Gill, 1981). Therefore, the NTVZ has been envisaged over decades as the westernmost segment of the Ryukyu volcanic arc (see Chen, 1990 for a review). Its generation, inevitably, has been ascribed to a southwestward encroachment of the Ryukyu Trench and accompanying propagation of the western boundary of the subducting Philippine Sea plate that could have commenced in the Plio-Pleistocene boundary as a response to southwestward develop- ment of the collisional tectonism in Taiwan (Suppe, 1984; Teng et al., 1992).

However, there are problems in considering the NTVZ as part of the Ryukyu volcanic arc. These include the $\sim 150 \mathrm{~km}$ horizontal displacement from the western end of the central Ryukyu volcanic arc, and the fact that the NTVZ is now sitting $\sim 200$ $250 \mathrm{~km}$ above the north-dipping Benioff zone of the southwestern Ryukyu subduction system (Eguchi 


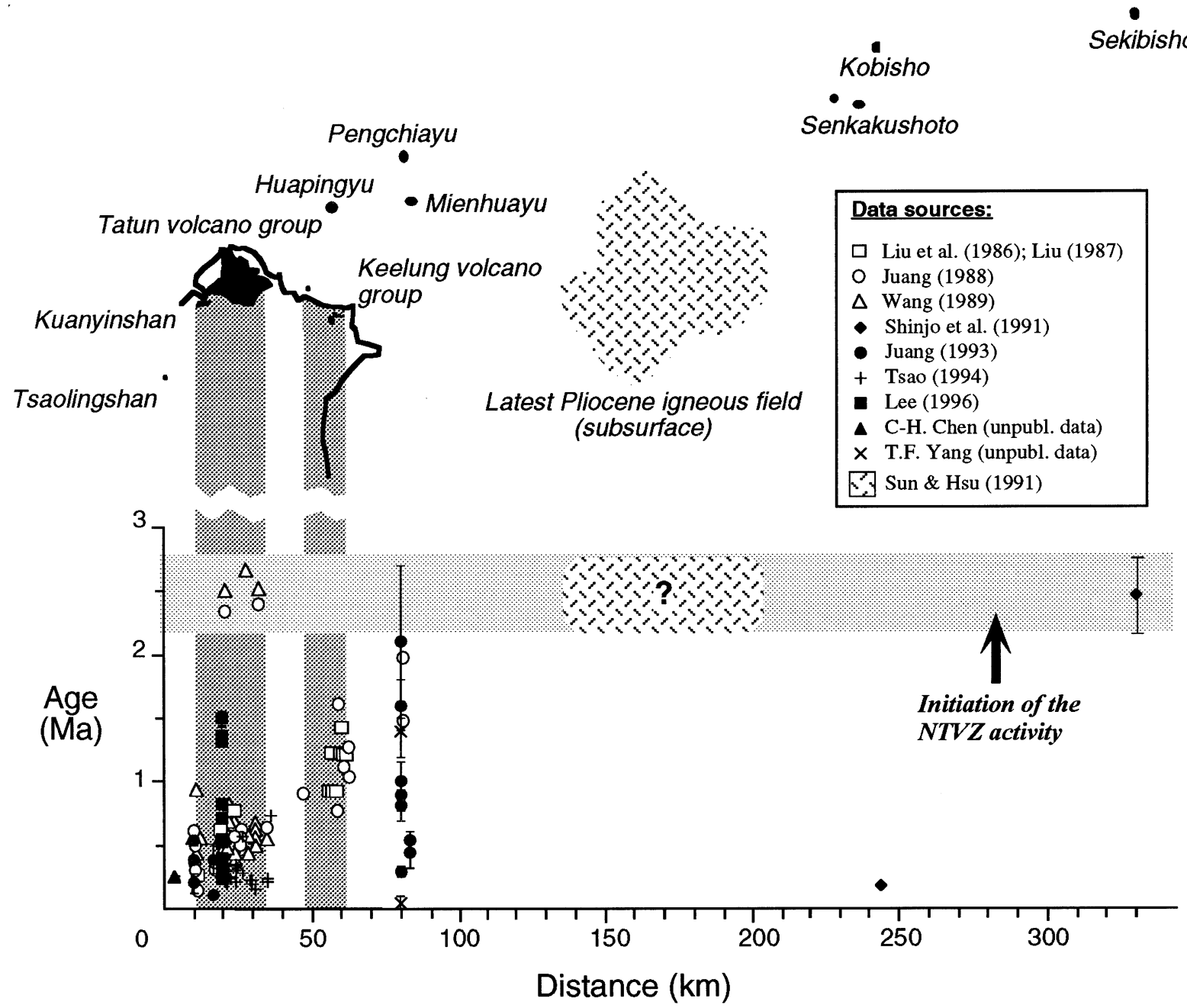

Fig. 2. Map showing locations and radiometric age data of each volcanic area in the NTVZ. Age data sources include: Liu et al. (1986), Liu (1987), Juang (1988), Wang (1989), Chen (1990), Shinjo et al. (1991), Sun and Hsu (1991), Juang (1993), Tsao (1994), Lee (1996) and our unpublished data. Note that in the entire NTVZ the volcanic activity began broadly synchronously at $\sim 2.5$ Ma and lasted until recently ( $\leq 0.2 \mathrm{Ma})$. The southwestward-younging trend reported by Teng et al. (1992) is not observed.

and Uyeda, 1983; Kao et al., 1998). Likewise, apparent differences in volcanic durations exist between the NTVZ and central Ryukyu arc, as the latter has become dormant since the earliest Pliocene (Shinjo, 1998). These 'inconsistencies' reflect that the NTVZ should be genetically distinctive from the Ryukyu arc whose volcanic front is essentially located along the 100-km-deep Benioff zone contour (Fig. 1). The NTVZ, together with the extensive subsurface volcanic field in the northeast offshore (Sun and Hsu, 1991), surrounds the northeastern Taiwan metamor- phic basement (Wageman et al., 1970), or the northern Taiwan orogenic belt (Fig. 1). This observation leads us to think of an alternative genetic process for the NTVZ, related to the orogenic collapse rather than affiliated directly with the Ryukyu subduction.

\section{Samples and methods}

Various types of volcanic samples were collected from different localities in the NTVZ for a detailed 
geochemical investigation which involves wholerock major and trace element, and $\mathrm{Sr}-\mathrm{Nd}-\mathrm{Pb}$ isotope determinations. In this paper, we simply focus on the spatial geochemical variation observed in the NTVZ and its tectonic implications. Discussion of the full set of geochemical data, however, is beyond the scope of this paper and will be given in a separate article. Table 1 presents major and trace element compositions of representative mafic rock samples used in the following discussion. Rock samples were roughly crushed, hand-picked, and then powdered in a corundum mill. Major element compositions were carried out by X-ray fluorescence techniques using a Rigaku $^{\circledR}$ RIX-2000 spectrometer at the Department of Geology of the National Taiwan University. The analytical uncertainties are generally better than 5\% for all elements. Loss on ignition (LOI) was measured by routine procedures. For the trace element determination, powdered samples were dissolved by a $\mathrm{HF} / \mathrm{HNO}_{3}(10: 1)$ mixture in screw-top Teflon beakers, evaporated to dryness, refluxed with $7 \mathrm{~N}$ $\mathrm{HNO}_{3}$ and dried again, and then dissolved in 2\% $\mathrm{HNO}_{3}$. Solutions thus obtained were measured by inductively coupled plasma-mass spectrometry (ICPMS) using a Perkin Elmer ${ }^{\circledR}$ Elan-6000 spectrometer at the Guangzhou Institute of Geochemistry, Chinese Academy of Sciences, which has a good stability range within $\sim 5 \%$ variation. Detailed analytical procedures have been reported by Liu et al. (1996). The analytical errors are generally better than $5 \%$ for most trace elements.

\section{Discussion and conclusions}

\subsection{Geochemical variation in the NTVZ}

As pointed out by Chen (1990), both the Tatun and Keelung volcano groups are composed of calcalkaline rocks with a dominance of andesites. Magmas from most offshore volcanic islets and the Tsaolingshan, by contrast, are more mafic and consist commonly of basalts and basaltic andesites. In the diagram of $\mathrm{K}_{2} \mathrm{O}$ versus $\mathrm{SiO}_{2}$ (Fig. 3), these NTVZ volcanics overall plot from low-K through calc-alkaline to shoshonitic compositions. Furthermore, the mafic rocks in combination display a spatial geochemical variation that is constrained by the
Sekibisho basalts in the northeast with low-K series affinities and the Tsaolingshan lavas in the southwest with a high-K shoshonitic nature. Such a variation, characterized by a southwestward increase in potash enrichment and silica undersaturation (Fig. 3), can be interpreted either by progressive southwestward decrease in degrees of partial melting (and/or increase in depths of partial melting; e.g., Kushiro, 1969), or by southwestward increase in involvement of a K-rich component within the mantle source regions during magma generation.

This spatial variation is also demonstrated by the incompatible trace element systematics (Fig. 4). Starting from the Sekibisho in the northeast, a southwestward increase in enrichment of large ion lithophile elements (LILE; i.e., $\mathrm{Cs}, \mathrm{Rb}, \mathrm{Ba}$, Th, and $\mathrm{U}$ ) and light rare earth elements (LREE; La and Ce) for the NTVZ magmas is observed. Moreover, all volcanic rocks except those from the Mienhuayu (see below) show 'arc-like' features characterized by LILE enrichment and depletion of the high field strength elements (HFSE; Nb, Ta and Ti). Emplaced in the southwesternmost, the Tsaolingshan lavas are extremely LILE-enriched but possess the lowest abundances of the heavy rare earth elements (Fig. 4). These juvenile $(\sim 0.2 \mathrm{Ma})$ rocks are highly magnesian $(\mathrm{MgO} \approx 15 \mathrm{wt} \%)$ and ultrapotassic $\left(\mathrm{K}_{2} \mathrm{O}\right.$ $\approx 5 \mathrm{wt} \% ; \mathrm{K}_{2} \mathrm{O} / \mathrm{Na}_{2} \mathrm{O}>3$; Table 1 ), but depleted in the 'basaltic component' (e.g., $\mathrm{Al}_{2} \mathrm{O}_{3}$, total $\mathrm{FeO}$ and $\mathrm{CaO}$ ). Thus, they have been considered as being derived from a small degree melting of a metasomatized, phlogopite-bearing harzburgitic source region in the lithospheric mantle (Chung et al., 1995b).

These data enable us to conclude that there exists a spatial geochemical variation in the NTVZ. This variation scheme, running approximately parallel to the present-day southwestern Ryukyu Trench, is distinguishable from that revealed by the subduction zone magmas whose compositions often vary in being perpendicular to the direction of trenches (Gill, 1981). Two 'misfits' in the proposed geochemical variation, i.e., the Kobisho and the Mienhuayu (see below), need to be explained. The Kobisho magmas show a higher potassium content, thus plotting away from the neighboring Sekibisho rocks in the $\mathrm{K}_{2} \mathrm{O}$ versus $\mathrm{SiO}_{2}$ diagram (Fig. 3). Despite the presence of alkalis, and a relatively stronger enrichment in LILE, however, their incompatible trace element 
Table 1

Major and trace element data of representative volcanic rocks from the Northern Taiwan Volcanic Zone

\begin{tabular}{|c|c|c|c|c|c|c|c|c|c|c|c|c|}
\hline & \multicolumn{2}{|c|}{ Sekibisho $^{a}$} & \multirow{2}{*}{$\begin{array}{l}\text { Kobisho } \\
\text { KO-4 }\end{array}$} & \multicolumn{2}{|c|}{ Mienhuayu } & \multirow{2}{*}{$\begin{array}{l}\text { Pengchiayu } \\
\text { Pgu-05 }\end{array}$} & \multicolumn{2}{|c|}{ Tatun Group } & \multicolumn{2}{|c|}{ Kuanyinshan } & \multicolumn{2}{|c|}{ Tsaolingshan } \\
\hline & SBS-1 & SBS-7 & & МHH01 & Pen-20 & & A-99 & A-129 & $\mathrm{K}-41$ & K-64 & TLS-8 & TLS-27 \\
\hline \multicolumn{13}{|c|}{ Major elements (in wt\%) } \\
\hline $\mathrm{SiO}_{2}$ & 49.91 & 50.15 & 50.02 & 54.50 & 51.18 & 53.54 & 52.61 & 49.27 & 51.43 & 50.42 & 48.36 & 47.03 \\
\hline $\mathrm{TiO}_{2}$ & 0.88 & 1.02 & 0.83 & 1.44 & 1.19 & 1.19 & 0.81 & 1.54 & 0.85 & 1.07 & 0.81 & 0.80 \\
\hline $\mathrm{Al}_{2} \mathrm{O}_{3}$ & 20.27 & 18.84 & 17.49 & 14.60 & 17.24 & 15.40 & 18.86 & 17.38 & 17.08 & 14.85 & 12.20 & 12.86 \\
\hline $\mathrm{Fe}_{2} \mathrm{O}_{3} \mathrm{~b}$ & 11.29 & 12.33 & 9.13 & 10.39 & 9.49 & 9.87 & 8.05 & 9.54 & 8.27 & 8.33 & 7.25 & 7.35 \\
\hline $\mathrm{MnO}$ & 0.17 & 0.18 & 0.16 & 0.14 & 0.15 & 0.14 & 0.14 & 0.17 & 0.17 & 0.15 & 0.13 & 0.13 \\
\hline $\mathrm{MgO}$ & 4.38 & 4.73 & 5.95 & 7.38 & 5.45 & 6.47 & 4.55 & 5.95 & 7.71 & 8.40 & 14.83 & 15.23 \\
\hline $\mathrm{CaO}$ & 10.44 & 10.16 & 11.81 & 8.48 & 10.33 & 9.19 & 9.15 & 10.64 & 9.29 & 10.43 & 7.27 & 7.16 \\
\hline $\mathrm{Na}_{2} \mathrm{O}$ & 2.97 & 2.88 & 2.11 & 2.14 & 2.43 & 1.77 & 2.50 & 2.23 & 2.72 & 2.17 & 1.89 & 1.77 \\
\hline $\mathrm{K}_{2} \mathrm{O}$ & 0.26 & 0.36 & 1.74 & 0.40 & 1.46 & 0.95 & 1.70 & 1.42 & 1.69 & 1.72 & 4.82 & 5.03 \\
\hline $\mathrm{P}_{2} \mathrm{O}_{5}$ & 0.10 & 0.15 & 0.42 & 0.13 & 0.39 & 0.28 & 0.20 & 0.25 & 0.48 & 0.34 & 1.55 & 1.53 \\
\hline LOI & 1.67 & 1.17 & 0.62 & 1.51 & 1.23 & 04.26 & 0.21 & 0.18 & 0.08 & 2.41 & 0.01 & 0.80 \\
\hline \multicolumn{13}{|c|}{ Trace elements (in ppm) } \\
\hline Cs & 0.28 & 0.30 & 1.26 & 0.51 & 0.92 & 0.68 & 8.04 & 4.85 & 3.83 & 1.95 & 167 & 124 \\
\hline $\mathrm{Rb}$ & 5.6 & 6.2 & 64.1 & 15.6 & 42.4 & 28.9 & 71.4 & 45.3 & 98.7 & 85.2 & 1412 & 1068 \\
\hline $\mathrm{Ba}$ & 87 & 137 & 232 & 137 & 371 & 232 & 358 & 388 & 629 & 539 & 968 & 922 \\
\hline Th & 0.57 & 0.99 & 1.80 & 1.15 & 1.74 & 1.42 & 6.37 & 5.26 & 10.5 & 7.9 & 19.6 & 18.7 \\
\hline $\mathrm{U}$ & 0.20 & 0.31 & 0.53 & 0.32 & 0.50 & 0.42 & 2.78 & 1.42 & 4.86 & 3.39 & 18.4 & 17.5 \\
\hline $\mathrm{Nb}$ & 1.90 & 2.50 & 4.24 & 6.45 & 6.31 & 4.69 & 5.26 & 9.44 & 14.1 & 17.8 & 17.1 & 16.2 \\
\hline $\mathrm{Ta}$ & 0.15 & 0.19 & 0.23 & 0.38 & 0.47 & 0.29 & 0.47 & 0.60 & 0.74 & 0.99 & 0.93 & 0.86 \\
\hline $\mathrm{Pb}$ & 2.18 & 2.38 & 3.01 & 2.24 & 5.61 & 2.06 & 10.4 & 8.87 & 15.1 & 12.1 & 27.1 & 20.9 \\
\hline $\mathrm{Sr}$ & 268 & 392 & 419 & 187 & 524 & 342 & 424 & 404 & 770 & 630 & 733 & 704 \\
\hline $\mathrm{Zr}$ & 55 & 67 & 88 & 92 & 92 & 82 & 65 & 103 & 121 & 113 & 121 & 117 \\
\hline Hf & 1.35 & 1.86 & 2.19 & 2.61 & 2.50 & 2.55 & 1.76 & 2.93 & 3.08 & 2.90 & 3.17 & 3.04 \\
\hline $\mathrm{Y}$ & 21.8 & 26.6 & 18.4 & 22.2 & 26.6 & 22.1 & 16.5 & 21.2 & 21.9 & 20.7 & 14.8 & 14.6 \\
\hline V & 301 & 277 & 263 & 170 & 232 & 174 & 292 & 266 & 257 & 309 & 190 & 189 \\
\hline $\mathrm{Ga}$ & & & 18.3 & 18.7 & 19.4 & 18.1 & 19.0 & 19.7 & 19.8 & 17.7 & 12.8 & 12.8 \\
\hline $\mathrm{Cu}$ & & & 83 & 39 & 37 & 36 & 101 & 93 & 49 & 92 & 39 & 34 \\
\hline $\mathrm{Zn}$ & & & 70 & 110 & 91 & 82 & 66 & 76 & 69 & 61 & 58 & 58 \\
\hline $\mathrm{Sc}$ & 32.8 & 30.0 & 32.6 & 21.5 & 44.0 & 24.3 & 34.3 & 33.6 & 34.6 & 48.5 & 29.5 & 27.7 \\
\hline Co & 29 & 31 & 35 & 42 & 42 & 34 & 44 & 36 & 34 & 43 & 46 & 47 \\
\hline $\mathrm{Ni}$ & 27 & 33 & 65 & 138 & 22 & 66 & 13 & 23 & 106 & 94 & 466 & 484 \\
\hline $\mathrm{Cr}$ & 35 & 24 & 144 & 371 & 42 & 307 & 23 & 70 & 249 & 292 & 958 & 1054 \\
\hline $\mathrm{La}$ & 3.83 & 7.16 & 7.90 & 5.60 & 11.0 & 7.70 & 14.0 & 16.8 & 28.3 & 22.5 & 24.7 & 23.9 \\
\hline $\mathrm{Ce}$ & 9.36 & 17.5 & 17.8 & 12.4 & 22.3 & 17.4 & 25.3 & 37.5 & 54.0 & 43.0 & 49.0 & 47.7 \\
\hline $\operatorname{Pr}$ & 1.46 & 2.54 & 2.41 & 1.73 & 3.25 & 2.45 & 3.17 & 4.94 & 6.41 & 5.17 & 5.93 & 5.77 \\
\hline $\mathrm{Nd}$ & 7.16 & 12.0 & 10.7 & 8.90 & 15.2 & 11.8 & 13.2 & 20.6 & 24.2 & 20.3 & 23.7 & 23.2 \\
\hline $\mathrm{Sm}$ & 2.24 & 3.36 & 2.85 & 3.15 & 4.11 & 3.68 & 3.11 & 4.66 & 4.36 & 4.14 & 4.47 & 4.36 \\
\hline $\mathrm{Eu}$ & 0.83 & 1.15 & 1.01 & 1.22 & 1.40 & 1.38 & 0.95 & 1.44 & 1.31 & 1.26 & 1.09 & 1.06 \\
\hline $\mathrm{Gd}$ & 2.74 & 3.79 & 3.41 & 4.07 & 4.53 & 4.09 & 2.89 & 4.52 & 3.75 & 3.87 & 3.50 & 3.53 \\
\hline $\mathrm{Tb}$ & 0.49 & 0.64 & 0.55 & 0.66 & 0.74 & 0.73 & 0.51 & 0.68 & 0.59 & 0.59 & 0.47 & 0.46 \\
\hline Dy & 3.33 & 4.19 & 3.32 & 3.90 & 4.43 & 4.35 & 2.69 & 3.86 & 3.46 & 3.48 & 2.47 & 2.42 \\
\hline Ho & 0.74 & 0.91 & 0.70 & 0.75 & 0.90 & 0.86 & 0.64 & 0.80 & 0.71 & 0.71 & 0.48 & 0.48 \\
\hline $\mathrm{Er}$ & 2.16 & 2.67 & 2.03 & 1.95 & 2.45 & 2.26 & 1.60 & 2.23 & 2.07 & 1.99 & 1.37 & 1.35 \\
\hline $\mathrm{Tm}$ & 0.34 & 0.41 & 0.29 & 0.29 & 0.34 & 0.33 & 0.27 & 0.32 & 0.32 & 0.30 & 0.21 & 0.20 \\
\hline $\mathrm{Yb}$ & 2.15 & 2.62 & 2.66 & 1.69 & 2.09 & 1.99 & 1.58 & 1.96 & 2.15 & 1.89 & 1.29 & 1.26 \\
\hline $\mathrm{Lu}$ & 0.32 & 0.39 & 0.31 & 0.25 & 0.32 & 0.28 & 0.24 & 0.30 & 0.33 & 0.29 & 0.20 & 0.19 \\
\hline
\end{tabular}

a Data from Shinjo (1998).

b Total iron. 


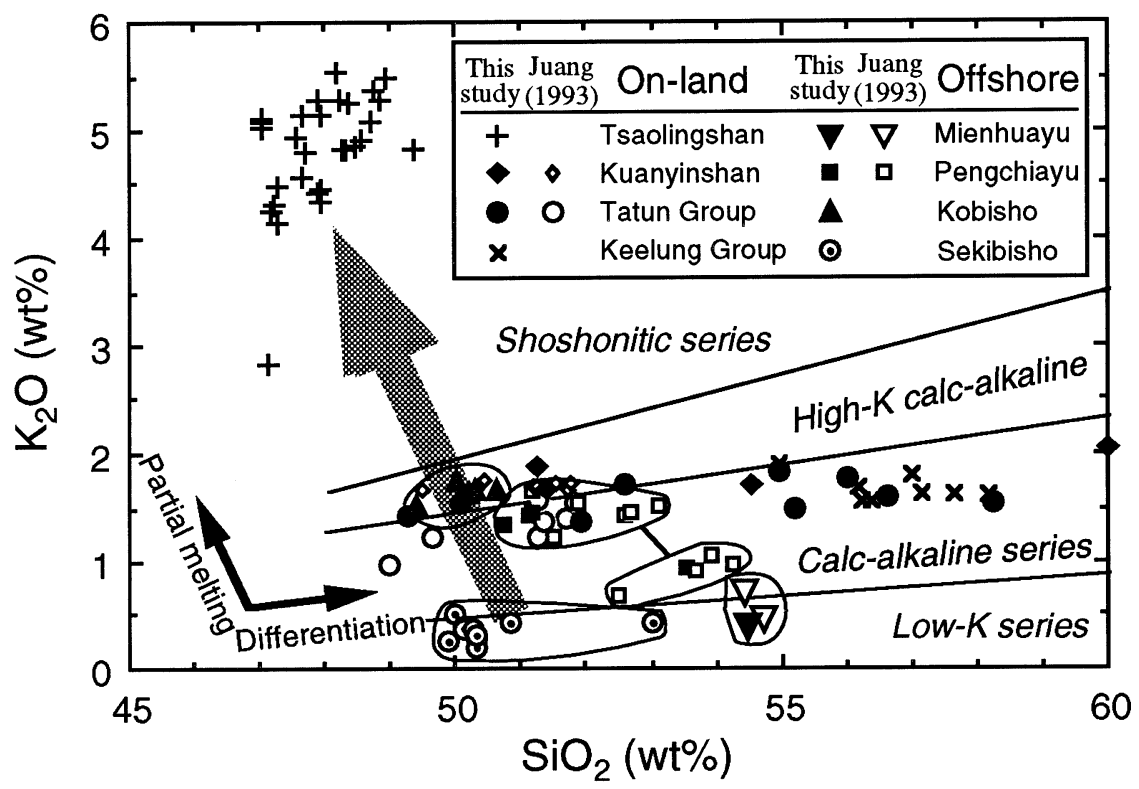

Fig. 3. $\mathrm{K}_{2} \mathrm{O}$ versus $\mathrm{SiO}_{2}$ diagram for volcanic rocks from the NTVZ. Offshore data for each volcanic area are encircled for clarity and two groups are subdivided for the Pengchiayu samples. The broad arrow indicates the proposed spatial geochemical variation. Boundaries of the rock series are according to Gill (1981).

characteristics are generally consistent with the spatial variation scenario (Fig. 4). Whereas the older Sekibisho magmas ( 2.6 Ma; Shinjo et al., 1991) show geochemical features that are comparable to the back-arc basin basalts from the middle Okinawa Trough and suggest an asthenospheric origin, generation of the younger $(\leq 0.2 \mathrm{Ma})$ Kobisho lavas in the nearby area requires the contribution by an enriched continental lithospheric mantle component (Shinjo, 1998). Such an enriched component is likely to be characterized by higher $\mathrm{K}$ and LILE abundances. A similar local compositional variation is also present in the Pengchiayu in the middle part of the NTVZ, where two volcanic groups with different potassium contents can be delineated (Fig. 3).

Our recent $\mathrm{Ar}-\mathrm{Ar}$ dating results reveal that eruption on the Mienhuayu began around $\sim 0.5 \mathrm{Ma}$ and lasted until recently (<0.1 Ma; Wang et al., 1999; Chen, unpubl. data). The Mienhuayu volcanics possess rather uniform chemical compositions, with $\mathrm{SiO}_{2}$ $\approx 54.5 \mathrm{wt} \%$ and $\mathrm{MgO} \approx 7.5 \mathrm{wt} \%$ (Table 1 ), similar to the boninites or high-magnesian andesites found exclusively in the fore-arc regions of hot and refractory mantle sources (Crawford et al., 1989). However, the Mienhuayu rocks show a smooth, moder- ately enriched incompatible element variation pattern without HFSE depletion (Fig. 4). Their overall geochemical features are different from those of highmagnesian andesites and other NTVZ volcanics, but similar to those of mid-Miocene $(\sim 13 \mathrm{Ma})$ basaltic andesites from the Iriomote-jima, southern Ryukyus (Shinjo et al., 1999) and broadly synchronous ( 13-9 Ma) tholeiitic basalts in northwestern Taiwan (Chung et al., 1995a) which both have been related to lithospheric extension in the East Asian continental margin existing before the Luzon arc indentation. Similar to these extension-induced magmas, the Mienhuayu volcanics show the following nonradiogenic $\mathrm{Sr}$ and $\mathrm{Nd}$ isotopic ratios: ${ }^{87} \mathrm{Sr} /{ }^{86} \mathrm{Sr} \approx 0.70435$ to $0.70455,{ }^{143} \mathrm{Nd} /{ }^{144} \mathrm{Nd} \approx 0.51290$ to 0.51300 (Wang et al., 1999). Thus, an ascended asthenospheric source region which had been rarely affected by the Ryukyu subduction zone processes has been proposed for the generation of the Mienhuayu magmas with intraplate geochemical affinities.

\subsection{Extension vs. subduction models}

Teng (1996) has postulated a tectonomagmatic model for the northern Taiwan orogenic evolution, 


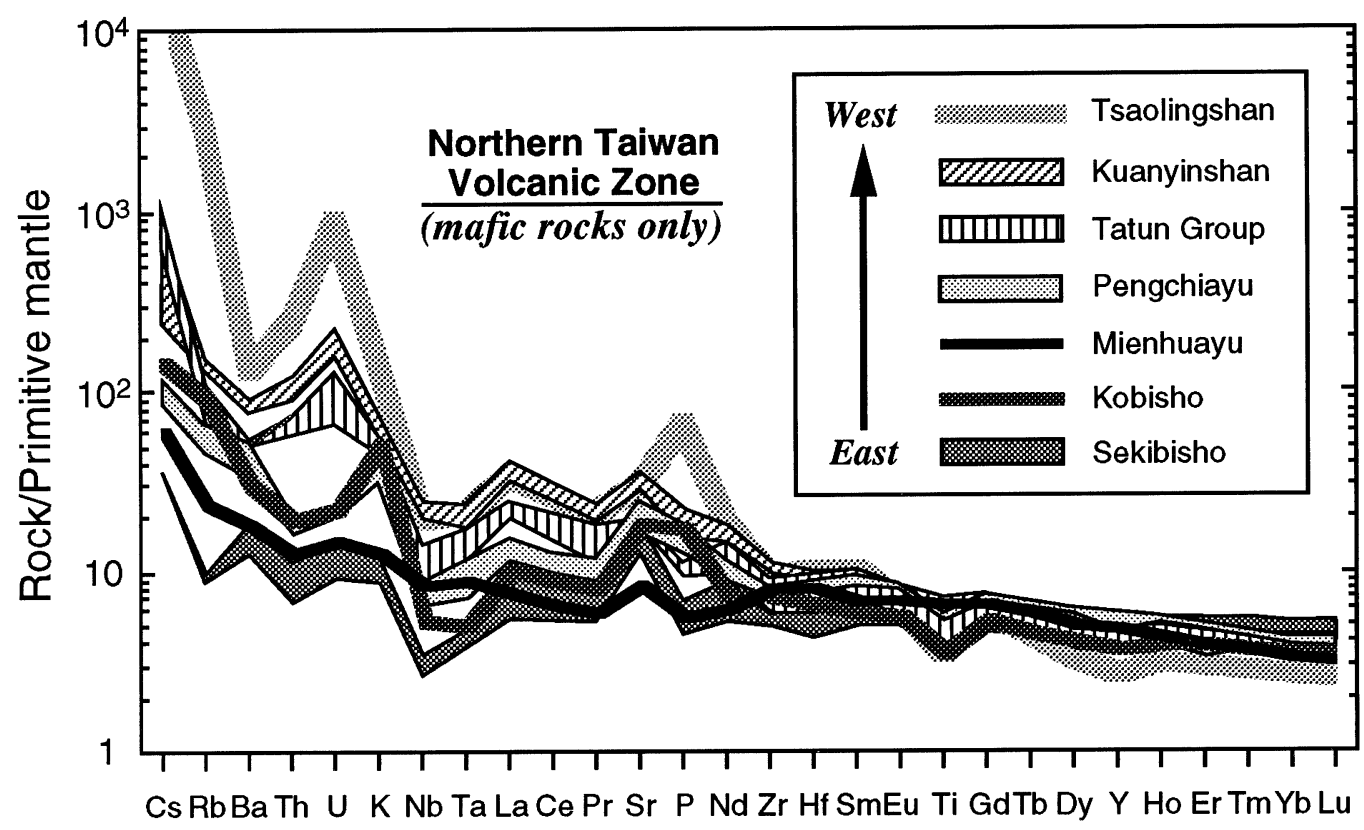

Fig. 4. Primitive-mantle-normalized diagram for volcanic rocks from the NTVZ. Note that for each volcanic area only mafic members are plotted. Normalizing values are from Sun and McDonough (1989).

in which the NTVZ is regarded as part of the Ryukyu volcanic arc and thus develops as a result of southwestward flipping of the Ryukyu subduction after Plio-Pleistocene extensional collapse of the northern Taiwan mountain belt. One of his standpoints, adopted from Teng et al. (1992), is that both the onset and cessation of the NTVZ activity migrated from the northeast to the southwest and hence each volcano was active only for a short period of less than one million years. This southwestward-younging volcanic activity trend, however, is not valid if new $\mathrm{K}-$ $\mathrm{Ar}$ and $\mathrm{Ar}-\mathrm{Ar}$ dating results are included (Shinjo et al., 1991; Tsao, 1994; Lee, 1996). The volcanism, lasting from the latest Pliocene to the Quaternary (Fig. 2), reveals a rather random age distribution. The most recent eruptions $(<0.2 \mathrm{Ma})$, for example, took place in the whole volcanic province in the Kobisho, Mienhuayu and Pengchiayu islets, and the Tatun and Tsaolingshan volcanoes. It is important to note that a directly subduction-initiated origin for the NTVZ has to encounter the fatal difficulties mentioned earlier in this paper but yet accommodated by Teng (1996). This model, moreover, can hardly be reconciled with the spatial geochemical variation observed.
It has been recognized in several Tertiary collision zones that magmatism may occur when collision-formed orogens begin collapsing (e.g., Dewey, 1988; Malavielle, 1993). We here propose that the NTVZ resulted from post-collisional extension related to orogenic collapse of the northern Taiwan mountain belt. The age of the NTVZ initiation, i.e. $\sim 2.8-2.5 \mathrm{Ma}$, therefore serves as a straightforward time constraint on the onset of the collapse. This time constraint is in good accordance with stratigraphic and structural data from sedimentary basins in northeast offshore Taiwan (e.g., Sun and Hsu, 1991; Huang et al., 1992). In these basins, extension-induced Tertiary strata had been inverted during the Late Miocene ( 7-6 Ma) because of the arccontinent collision in Taiwan. A thrust faulting system thus produced, however, was reset around PlioPleistocene time owing to orogenic collapse in northern Taiwan that resulted in normal faults associated with extensive igneous activity (Huang et al., 1992; Teng, 1996; Hsiao, 1997; Sibuet et al., 1998). Such an extensional collapse, probably caused by removal of the lower part of collision-thickened continental lithosphere and replacement of hotter asthenosphere 
(cf. Platt and England, 1993), could have significantly perturbed the geotherm and thus triggered partial melting in the upper mantle domains if they had been enriched by certain metasomatic processes such as subduction-related dehydration.

Our model rejects the conventional notion that links the NTVZ generation directly with the southwestern Ryukyu subduction. As pointed out by Chen (1997), in addition to the apparent discontinuity in geography, the NTVZ rocks have overall trace element systematics different from those of the Ryukyu arc volcanics. This distinction is clearly shown by a $\mathrm{Nb} / \mathrm{La}$ versus $\mathrm{Ba} / \mathrm{Rb}$ plot (Fig. 5), according to which three magma source components may be identified. Whereas most data plot in or close to the field defined by Central Ryukyu arc volcanics which constrain the 'subduction component' related to the Ryukyu subduction zone processes, two additional components are represented by the Mienhuayu rocks characterized by an OIB/E-MORB affinity and the Tsaolingshan rocks with extremely low $\mathrm{Ba} / \mathrm{Rb}$ ratios, respectively. The former, showing intraplate geochemical features, can be interpreted as an asthenospheric source which ascended as a response to the lithospheric extension and thinning (Wang et al., 1999). The latter, as envisaged by Chung et al. (1999), is most likely to reside in the refractory lithospheric mantle that has undergone a fluid-related metasomatism caused by dehydration from the nascent southwestern Ryukyu subduction zone. Therefore, the $\mathrm{Ba} / \mathrm{Rb}$ ratio, which is generally uniform in non-orogenic lavas $(\sim 11)$ and unfractionated by igneous processes (cf. Rogers et al., 1987), has been strongly fractionated due to preferential partitioning of $\mathrm{Rb}$ over $\mathrm{Ba}$ in the subducting slabreleased fluid (Tatsumi et al., 1986). Note that the term 'subduction component' reflects the widely acknowledged compositional feature unique to convergent-margin magmas owing to enrichment by water released from the subducting slab (Pearce and Peate, 1995). This component could have been imparted into the upper mantle domains beneath the northern

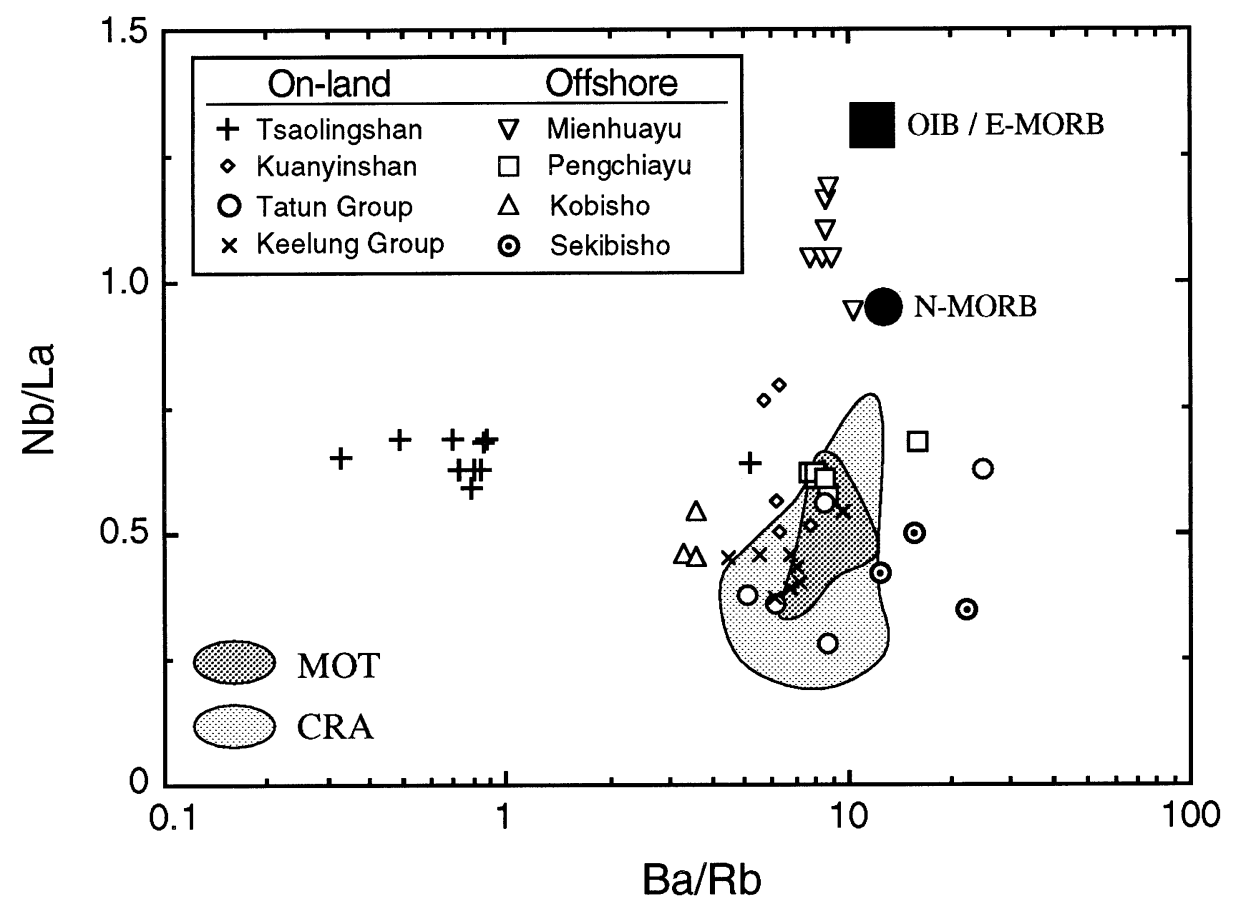

Fig. 5. $\mathrm{Nb} / \mathrm{La}$ versus $\mathrm{Ba} / \mathrm{Rb}$ diagram for volcanic rocks from the NTVZ. Symbols are the same as in Fig. 3. For comparison, the fields of volcanic rocks from the middle Okinawa Trough (MOT) and central Ryukyu arc (CRA) reported by Shinjo et al. (1999) are shown. Values for OIB (i.e. ocean island basalts), E-MORB and N-MORB (enriched and normal types of mid-ocean ridge basalts, respectively) are taken from Sun and McDonough (1989). The value of continental crust is from Rudnick and Fountain (1995). 
Taiwan mountain belt during its build-up stage from the neighboring Ryukyu subduction, whose central part has existed since probably the Early Miocene (Shinjo et al., 1999), which, however, migrated to the southwest only in the Quaternary after the orogenic collapse (see below).

The post-collisional extension model, furthermore, may account for the spatial geochemical variation observed in the NTVZ. Collapse of the northern Taiwan orogen, as described by Teng (1996), has most prominently developed in the area off northeast Taiwan and weakens to the southwest as a result of the ongoing collision around central Taiwan. A southwestward-diminishing extensional regime thus formed probably led to a southwestward decrease in degrees of the mantle melting. Consequently, magmas in the northeast offshore islets were produced by larger degrees of melting of the enriched upper mantle domains due to more significant lithospheric thinning and asthenospheric upwelling. The inference of eruptions of the Mienhuayu lavas from $\sim 0.5$ $\mathrm{Ma}$ is hence that an upper mantle doming (Fig. 6a) has been established in the region and, since that time, the ascended asthenosphere involved in the melt generation has been characterized by an OIBor E-MORB-type component. On the other hand, the Tsaolingshan magmas emplaced in the southwest resulted from smaller degrees of melting of a fluidenriched, phlogopite-bearing lithospheric mantle source that could be preferentially melted in the initial stage of extension in the margin of the NTVZ because of its substantially lower solidus temperature.

\subsection{Relation with the Okinawa Trough opening}

The Okinawa Trough is a curved back-arc basin located behind the Ryukyu arc-trench system, with its main curvature being restricted to the southwestern part (Fig. 1). Two major phases of extension, from the Middle to the Late Miocene (i.e. from $>15 \mathrm{Ma}$ to $\sim 6 \mathrm{Ma}$; Letouzey and Kimura, 1986; Park, 1996) and from the Early to the Late Pleistocene $(\leq 2 \mathrm{Ma})$, respectively, have been identified within the middle Okinawa Trough where modern tectonism $(\leq 0.1 \mathrm{Ma})$ is most active (cf. Sibuet et al., 1995). Both the cessation of the first extensional phase and the beginning of the second are commonly attributed to the arc-continent collision in Taiwan.
Several different models, such as trench retreat with lateral anchoring (Viallon et al., 1986), the Ryukyu arc rotation (Miki, 1995) and reconstruction based on normal fault patterns (Hsu et al., 1996), have been proposed for opening of the Okinawa Trough (see Sibuet et al., 1998 for a recent review). Although a general consensus has been obtained for the tectonic evolution in the central-northern part where the Okinawa Trough behaves as a simple back-arc basin behind the Ryukyu arc-trench system, controversies exist particularly in the southwest because the Trough becomes a 'fore-arc' basin if the NTVZ, as conventionally, is regarded as part of the Ryukyu volcanic arc.

Our model for the NTVZ can accommodate the evolution of the southwestern Okinawa Trough. In the post-collisional extension scheme, we propose that the orogenic collapse of the northern Taiwan mountain belt played a role in the initiation of the second stage rifting in the middle Okinawa Trough and then gave way to its southwestward migration. Hsu et al. (1996) reported that west of $\sim 124^{\circ} \mathrm{E}$ the Okinawa Trough shows structural patterns different from those of the rest of the trough. It is hence reasonable to argue that two kinematic modes of the opening of the Okinawa Trough are necessary. In contrast to its central-northern part where there has been a simple back-arc basin, the present configuration of the southwestern Okinawa Trough (i.e. west of $124^{\circ} \mathrm{E}$ ) can be best described by a fanshaped opening starting $\sim 1.5 \mathrm{Ma}$ (Chiang and Lee, 1996; Lee et al., 1998) with a rapid southwestward propagation rate of $\sim 126 \mathrm{~mm} / \mathrm{yr}$ and a clockwise rotation of $\sim 1.3 \mu \mathrm{radian} / \mathrm{yr}$ based on geodetic monitoring data (Liu, 1995). Such an opening, perhaps responsible for formation of the curvature of the trough, might have been accompanied by the southwestward encroachment of the subducting Western Philippine Sea plate and the Ryukyu Trench. This nascent subduction subsequently resulted in a series of submarine volcanoes in this part of the Okinawa Trough which, according to Sibuet et al. (1998), delineate a volcanic front located $\sim 80-100 \mathrm{~km}$ above the Wadati-Benioff zone along the southern margin of the trough. Kueishantao, the only emerged volcano in the westernmost (Fig. 1), consists dominantly of calc-alkaline andesite lavas (Chen, 1990; Chen et al., 1995). Thermoluminescence dating of 


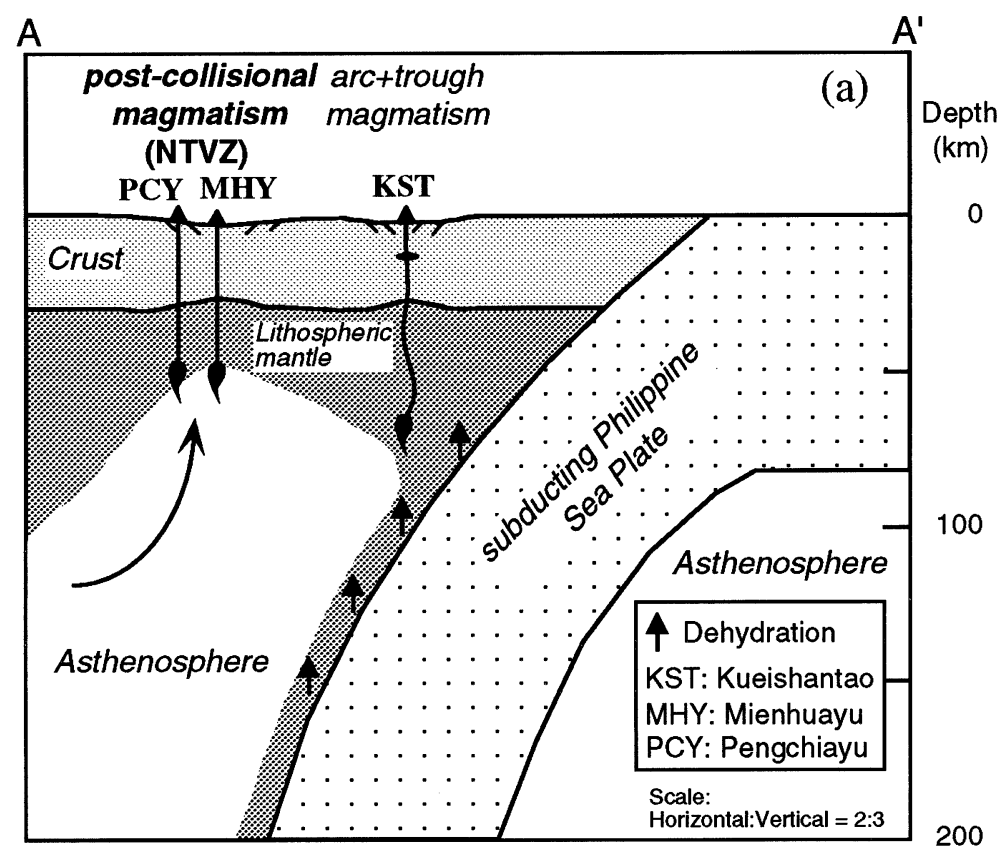

B

$B^{\prime}$

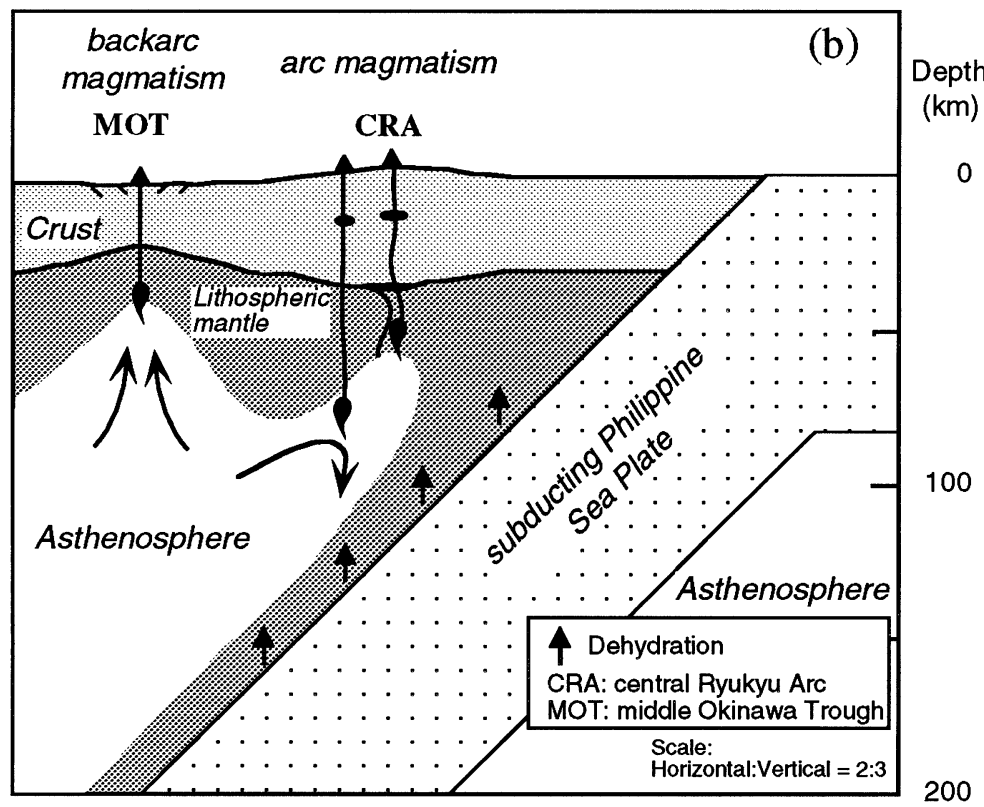

Fig. 6. Schematic profiles along the $A-A^{\prime}$ and $B-B^{\prime}$ lines (Fig. 1) showing the present-day mantle structures beneath (a) offshore northeast Taiwan and (b) the central Ryukyu arc-back-arc system, respectively. See text for discussion. Information and data used to construct these profiles include Pearce and Peate (1995) for the general arc-back-arc picture and Kao et al. (1998), Shinjo et al. (1999) and Sibuet et al. (1998) for specific geotectonic details in this region. 
quartz separates from a sandstone nodule captured by the Kueishantao lava suggests that the volcanic eruption took place $\sim 7000$ years ago $(7000 \pm 800$ yr BP; Chen et al., 1998). AMS ${ }^{14} \mathrm{C}$ dating of turbidites recovered from the slope of the southwestern Ryukyu Trench indicates that turbiditic currents occurred frequently in the past 10,000 years, owing to earthquakes caused by active subduction and probably volcanism (Ujiié et al., 1997). These lines of evidence support the notion that, west of $\sim 124^{\circ} \mathrm{E}$, both the Okinawa Trough and the Ryukyu arctrench represent embryonal geological features. In this sense, the southwestern Okinawa Trough is considered an atypical back-arc basin because it was formed before or at least contemporaneously with the arc-trench counterpart. All the above-mentioned tectonic and magmatic processes consequently led to the unique collision/extension/subduction context in this region.

Lastly, we construct two lithospheric sections to demonstrate spatial variation in the mantle structure beneath the southwestern and central parts of the Okinawa Trough-Ryukyu subduction system (Fig. 6). Note that, in the two sections, the relative position between the Okinawa Trough and the Ryukyu volcanic arc is suggested to be different. In the middle Okinawa Trough, where the continental lithosphere has been significantly attenuated and the asthenosphere ascended (Fig. 6b), a typical back-arc basin structure is observed $\sim 100 \mathrm{~km}$ behind the central Ryukyu arc and $\sim 200 \mathrm{~km}$ above the Wadati-Benioff zone (cf. Shinjo, 1998; Sibuet et al., 1998). By contrast, the southwestern Okinawa Trough (Fig. 6a) is sitting $\sim 100 \mathrm{~km}$ above the Wadati-Benioff zone with an embryonal volcanic front occurring along its southern margin (Sibuet et al., 1998). In the Kueishantao area, the trough topography and the volcanic front become merged. The NTVZ, which began its activity around the Plio-Pleistocene and is now located $\sim 200-250 \mathrm{~km}$ above the WadatiBenioff zone (Kao et al., 1998), is marked by a 'mantle doming' structure that is comparable to the middle Okinawa Trough (Fig. 6a). Partial melting of the adiabatically ascended asthenospheric mantle, which had been rarely affected by the Ryukyu subduction zone processes, is proposed for the generation of the Mienhuayu magmas with intraplate geochemical affinities.

\section{Acknowledgements}

Relevant information and comments provided by Tony Crawford, T.-Y. Lee and C.-H. Lo were of significant help in clarifying many aspects presented in this paper. This study benefited from a research grant (NSC 87-2611-M-002-001) from the National Science Council, Taiwan, Republic of China.

\section{References}

Angelier, J., Barrier, E., Chu, H.T., 1986. Plate collision and paleostress trajectories in a fold-thrust belt: the foothills of Taiwan. Tectonophysics 125, 161-178.

Chen, C.-H., 1990. Igneous rocks of Taiwan (in Chinese). Cent. Geol. Surv., Spec. Publ. 1, 137 pp.

Chen, C.H., 1997. Extensional collapse of the northern Taiwan mountain belt: comment. Geology 25, 855-856.

Chen, C.H., Lee, T., Shieh, Y.N., Chen, C.H., Hsu, W.Y., 1995. Magmatism at the onset of back-arc basin spreading in the Okinawa Through. J. Volcanol. Geotherm. Res. 69, 313-322.

Chen, Y.G., Wu, W.S., Liu, T.K., Chen, C.-H., 1998. A Holocene volcanic island: Kueishantao (in Chinese). Annu. Meet. Geol. Soc. China, Prog. Abstr., pp. 104-105.

Chiang, C.S., Lee, T.Y., 1996. Kinematics of the Okinawa Trough: Two modes of opening in Northeast offshore Taiwan. Eos 77, 733.

Chung, S.L., Jahn, B.M., Chen, S., Lee, T., Chen, C.-H., 1995a. Miocene basalts in northwestern Taiwan: Evidence for EMtype mantle sources in the continental lithosphere. Geochim. Cosmochim. Acta 59, 549-555.

Chung, S.L., Yang, T.F., Lee, C.Y., Chen, C.-H., 1995b. The igneous provinciality in Taiwan: Consequence of continental rifting superimposed by Luzon and Ryukyu subduction systems. J. SE Asian Earth Sci. 11, 73-80.

Chung, S.L., Wang, K.L., Crawford, A.J., Chen, C.-H., Lan, C.Y., Chen, C.H., 1999. Highly magnesian potassic magmas in the arc-continent collision belt of Taiwan: implications for the genesis of orogenic potassic lavas and the slab component of subduction zones. Contrib. Mineral. Petrol. (submitted).

Crawford, A.J., Falloon, T.J., Green, D.H., 1989. Classification, petrogenesis and tectonic setting of boninites. In: Crawford, A.J. (Ed.), Boninites and Related Rocks. Unwin and Hyman, London, pp. 1-49.

Dahlen, F.A., Suppe, J., 1988. Mechanics, growth and erosion of mountain belts. Geol. Soc. Am., Spec. Pap. 218, 161-178.

Davis, D., Suppe, J., Dahlen, F.A., 1983. Mechanics of fold-andthrust belts and accretionary wedges. J. Geophys. Res. 88, 1153-1172.

Dewey, J., 1988. Extensional collapse of orogens. Tectonics 7, 1123-1139.

Eguchi, T., Uyeda, S., 1983. Seismotectonics of the Okinawa Trough and Ryukyu Arc. Mem. Geol. Soc. China 5, 189-210. 
Gill, J.B., 1981. Orogenic Andesites and Plate Tectonics. Springer, Berlin, 390 pp.

Hirata, N., Kinoshita, H., Katao, H., Baba, H., Kaiho, Y., Koresawa, S., Ono, Y., Hayashi, K., 1991. Report on DELP 1988 cruises in the Okinawa Trough, Part 3. Crustal structure of the southern Okinawa Trough. Earthquake Res. Inst., Univ. Tokyo Bull. 66, 37-70.

Ho, C.S., 1986. A synthesis of the geologic evolution of Taiwan. Tectonophysics 125, 1-16.

Hsiao, L.Y., 1997. Late Cenozoic structure off northeastern Taiwan (in Chinese). MS thesis, Natl. Taiwan Univ., Taipei, 62 pp.

Hsu, S.-K., Sibuet, J.-C., 1995. Is Taiwan the result of arccontinent or arc-arc collision? Earth Planet. Sci. Lett. 136, $315-324$.

Hsu, S.-K., Sibuet, J.-C., Monti, S., Shyu, C.-T., Liu, C.-S., 1996. Transition between the Okinawa Trough backarc extension and the Taiwan collision: new insights on the southernmost Ryukyu subduction zone. Mar. Geophys. Res. 18, 163-187.

Huang, S.T., Ting, H.H., Chen, R.C., Chi, W.R., Hu, C.C., Shen, H.C., 1992. Basinal framework and tectonic evolution of offshore northern Taiwan. Pet. Geol. Taiwan 27, 47-72.

Juang, W.S., 1988. Geochronology and Chemical Variations of Late Cenozoic Volcanic Rocks in Taiwan (in Chinese). Ph.D. thesis, Natl. Taiwan Univ., Taipei, 231 pp.

Juang, W.S., 1993. Diversity and origin of Quaternary basaltic magma series in northern Taiwan. Bull. Natl. Mus. Nat. Sci. 4, $125-166$.

Kao, H., Shen, S.J., Ma, K.-F., 1998. Transition from oblique subduction to collision: earthquake in the southernmost Ryukyu arc-Taiwan region. J. Geophys. Res. 103, 7211-7229.

Kizaki, K., 1986. Geology and tectonics of the Ryukyu islands. Tectonophysics 125, 193-207.

Kushiro, I., 1969. The system forsterite-diopside-silica with and without water at high pressures. Am. J. Sci. 267, 269-294.

Lee, C.T., Wang, Y., 1988. Quaternary stress changes in northern Taiwan and their tectonic significance. Proc. Geol. Soc. China 31, 154-168.

Lee, S.F., 1996. Volcanic Sequence Study of the Tatun Volcano Group: The Chihsinshan Subgroup (in Chinese). MS thesis, Natl. Taiwan Univ., Taipei, 136 pp.

Lee, T.Y., Chiang, C.S., Kong, F., Chung, S.L., Lo, C.H., 1998. Kinematics of the opening of the southernmost part of Okinawa Trough (SPOT). Eos 79, 109.

Letouzey, J., Kimura, M., 1986. The Okinawa Trough: Genesis of a back-arc basin developing along a continental margin. Tectonophysics 125, 209-230.

Liu, C.C., 1995. The Ilan plan and the southwestward extending Okinawa Trough. J. Geol. Soc. China 38, 229-242.

Liu, T.K., 1987. Some new radiometric ages of rocks from Taiwan. Annu. Meet. Geol. Soc. China, Prog. Abstr., p. 62.

Liu, T.K., Chen, C.-H., Jiang, S.H., 1986. Fission-track study of igneous rocks from northern Taiwan. Unpubl. Rep. Natl. Sci. Council, Taiwan.

Liu, Y., Liu, H., Li, X.H., 1996. Simultaneous and precise determination of 40 trace elements in rock samples (in Chinese). Geochimica 25, 552-558.
Malavielle, J., 1993. Late orogenic extension in mountain belts: insights from the Basin and Range and the late Paleozoic Variscan belt. Tectonics 12, 1115-1130.

Miki, M., 1995. Two-phase opening model for the Okinawa Trough inferred from paleomagnetic study of the Ryukyu Arc. J. Geophys. Res. 100, 8169-8184.

Park, J.-O., 1996. Seismic Stratigraphy and Tectonic Evolution of the Southern Ryukyu Island Arc. Ph.D. thesis, Ocean Res. Inst., Univ. of Tokyo, 145 pp.

Pearce, J.A., Peate, D.W., 1995. Tectonic implications of the composition of volcanic arc magmas. Annu. Rev. Earth Planet. Sci. 23, 251-285.

Platt, J.P., England, P.C., 1993. Convective removal of lithosphere beneath mountain belts: thermal and mechanical consequences. Am. J. Sci. 293, 307-336.

Platt, J.P., Visser, R.L.M., 1989. Extensional collapse of thickened continental lithosphere: a working hypothesis for the Alboran Sea and Gibraltar arc. Geology 17, 540-543.

Rogers, N.W., Hawkesworth, C.J., Mattey, D.P., Harmon, R.S., 1987. Sediment subduction and the source of potassium in orogenic leucitites. Geology 15, 451-453.

Rudnick, R.L., Fountain, D.M., 1995. Nature and composition of the continental crust: a lower crustal perspective. Rev. Geophys. 33, 267-309.

Shinjo, R., 1998. Petrochemistry and tectonic significance of the emerged late Cenozoic basalts behind the Okinawa TroughRyukyu arc system. J. Volcanol. Geotherm. Res. 80, 39-53.

Shinjo, R., Ban, M., Saito, K., Kato, Y., 1991. K-Ar dating of the volcanic rocks in the Ryukyu arc (in Japanese). J. Mineral. Petrol. Econ. Geol. 86, 323-328.

Shinjo, R., Chung, S.L., Kato, Y., Kimura, M., 1999. Geochemical and $\mathrm{Sr}-\mathrm{Nd}$ isotopic characteristics of volcanic rocks from the Okinawa Trough and Ryukyu arc: implications for the evolution of a young, intra-continental backarc basin. J. Geophys. Res. (in press).

Sibuet, J.-C., Hsu, S.-K., Shyu, C.-T., Liu, C.-S., 1995. Structural and kinematic evolutions of the Okinawa Trough backarc basin. In: Taylor, B. (Ed.), Backarc Basins: Tectonics and Magmatism. Plenum Press, New York, pp. 343-379.

Sibuet, J.-C., Deffontaines, B., Hsu, S.-K., Thareau, N., Le Formal, J.-P., Liu, C.S. and the ACT party, 1998. The Okinawa Trough backarc basin: early tectonic and magmatic evolution. J. Geophys. Res. 103, 30245-30267.

Sun, S.C., Hsu, Y.Y., 1991. Overview of the Cenozoic geology and tectonic development of offshore and onshore Taiwan. TAICRUST Workshop Proc., pp. 35-47.

Sun, S.-s., McDonough, W.F., 1989. Chemical and isotopic systematics of oceanic basalts: implications for mantle composition and processes. In: Saunders, A.D., Norry, M.J. (Eds.), Magmatism in the Ocean Basins. Geol. Soc. Spec. Publ. 42, 313-345.

Suppe, J., 1981. Mechanics of mountain building in Taiwan. Mem. Geol. Soc. China 4, 67-89.

Suppe, J., 1984. Kinematics of arc-continent collision, flipping of subduction and back-arc spreading near Taiwan. Mem. Geol. Soc. China 6, 21-33.

Tatsumi, Y., Hamilton, D.L., Nesbitt, R.W., 1986. Chemical char- 
acteristics of fluid phase released from a subducted lithosphere and origin of arc magmas: Evidence from high-pressure experiments and natural rocks. J. Volcanol. Geotherm. Res. 29, 293-309.

Teng, L.S., 1990. Geotectonic evolution of late Cenozoic arccontinent collision in Taiwan. Tectonophysics 183, 57-76.

Teng, L.S., 1996. Extensional collapse of the northern Taiwan mountain belt. Geology 24, 949-952.

Teng, L.S., Chen, C.-H., Wang, W.S., Liu, T.K., Juang, W.S., Chen, J.C., 1992. Plate kinematic model for late Cenozoic arc magmatism in northern Taiwan. J. Geol. Soc. China 35, 1-18.

Tsao, S.J., 1994. Potassium-argon age determination of volcanic rocks from the Tatun volcano group (in Chinese). Bull. Cent. Geol. Surv. 9, 137-154.

Ujiié, H., Nakamura, T., Miyamoto, Y., Park, J.-O., Oyakawa, T., 1997. Holocene turbidite cores from the southern Ryukyu Trench slope: suggestions of periodic earthquakes. J. Geol. Soc. Jpn. 103, 590-603.

Viallon, C., Huchon, P., Barrier, E., 1986. Opening of the Oki- nawa basin and collision in Taiwan: a retreating trench model with lateral anchoring. Earth Planet. Sci. Lett. 80, 145-155.

Wageman, J.M., Hilde, T.W.C., Emery, K.O., 1970. Structure framework of East China Sea and Yellow Sea. Am. Assoc. Pet. Geol. Bull. 54, 1611-1643.

Wang, K.L., Chen, C.H., Chung, S.L., Lo, C.H., Chen, C-H., Yang, T.F., 1999. Ar-Ar dating and petrochemical characteristics of volcanic successions in the Mienhuayu off NE Taiwan. J. Geol. Soc. China (submitted).

Wang, W.S., 1989. Volcanic Geology and Fission Track Datings of the Tatun Volcano Group, Northern Taiwan (in Chinese). MS thesis, Natl. Taiwan Univ., Taipei, 154 pp.

Yeh, Y.H., Barrier, E., Lin, C.H., Angelier, J., 1991. Stress tensor analysis in the Taiwan area from focal mechanisms of earthquakes. Tectonophysics 200, 267-280.

Yu, S.B., Chen, H.Y., 1994. Global positioning system measurements of crustal deformation in the Taiwan arc-continent collision zone. TAO Sci. 5, 477-498. 